\title{
The Effect of Online Learning on Mathematics Value of Seventh Class Students in Bulu China Swadaya SMPS
}

\author{
Irwan, Mardiati, Lilis Saputri, Seget Tartiyoso, Efrini Panjaitan \\ STKIP Budidaya Binjai \\ Email: irwanmedan1960@gmail.com, mmardiati826@gmail.com, falinsyah16@gmail.com, \\ efrinipanjaitan@gmail.com
}

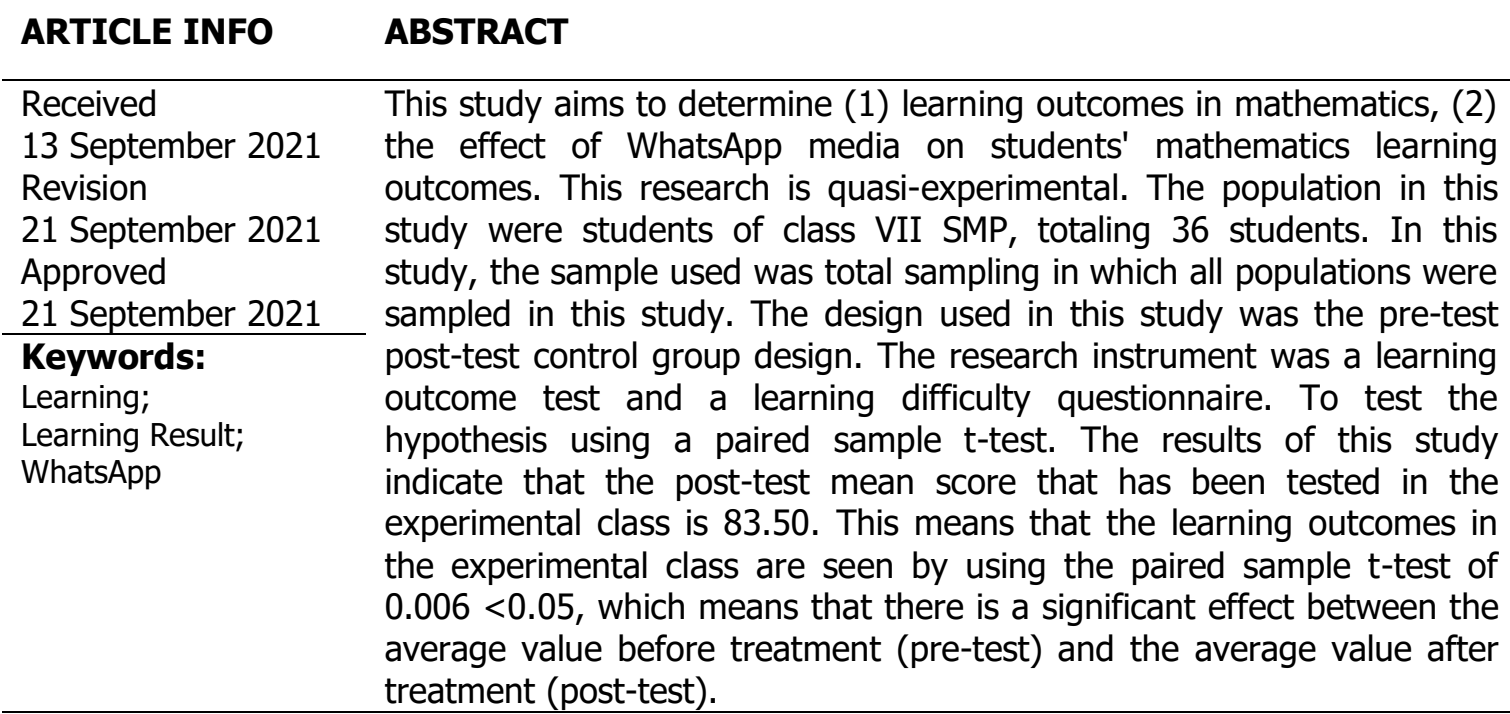

\section{INTRODUCTION}

According to Onno W. Purbo (Rusman \& Cepi, 2012), e-learning is a term used to support student learning efforts via the internet. Because the Covid-19 pandemic has hit all countries in the world, including Indonesia. According to the latest data from the World Health Organization (WHO) on April 24, 2020, as many as 213 countries have been infected with Covid-19, of which 2,631,839 were confirmed positive and 182,100 died. Covid-19 is an infectious disease, which means it can spread, either directly or indirectly, from one person to another. Therefore, in learning mathematics, students must also be able to develop in the context of e-learning (Albano, 2012). One way to break the chain of the spread of Covid-19 is to limit public interaction, which is applied by the term physical distancing. However, the physical distancing policy can hamper the rate of growth in various fields of life, both in the economic, social, and of course education fields. The government's decision to dismiss students, transfer the teaching and learning process at school becomes at home by implementing the Work from Home (WFH) policy,

which makes many parties nervous. (Yuliana, 2020).

However, the implementation of the online learning process has several obstacles. One of the toughest obstacles in online learning is teaching mathematics. The current problem is that there are still many students who consider mathematics a difficult subject. As (Auliya, 2016) argues, mathematics is considered a difficult subject because of the characteristics of mathematics that are abstract, logical, systematic, and full of confusing symbols and formulas. The difficulties that exist in mathematics subjects require the creativity of mathematics subject teachers to develop their learning, both in terms of methods and media used.

\footnotetext{
How To Cite: Irwan, I. et. al. (2021) The Effect of Online Learning on Mathematics Value of Seventh Class Students In Bulu China Swadaya SMPS. Journal of Social Science. 2(5). https://doi.org/10.46799/jss.v2i5.217 
About learning outcomes, distance learning such as the WhatsApp Group media is still a polemic among stakeholders and the community (Amaniyah, Rahmawati, \& Lailiyah, 2021). This is because distance learning is still considered no better than conventional direct learning, especially in learning mathematics. This is because in studying mathematics people have to think so that they can understand the mathematical concepts being studied and can use these concepts appropriately when they have to find answers to various math problems (Widada, 2015), while the thinking process cannot be obtained from distance learning (Fuady, 2017).

This problem arises not only because of the lack of students' learning abilities and motivation, but when researchers survey the extent to which WhatsApp media is used or how often teachers use media during learning. And it could be from the experience of students at home or at school, or it could be from the influence of television which could be the inhibiting factor (NURDIANTORO, 2018).

In this case, the effectiveness of teachers in managing learning has a very large influence on improving student learning outcomes. especially in Mathematics, which is mathematics, can be obtained by way of thinking (reasoning) (Solikhah, 2019)

The researcher also asked the teacher in question Mr. Supadi.S.Pd about the extent to which teachers use Whatsapp media when teaching and how the student learning outcomes have been so far. Because everyone will be held accountable for what they have done. (Adhe, 2021).

The teacher said that it is not always good to use WhatsApp media or when teaching in class. Because children who cannot learn properly due to obstacles or disturbances will experience difficulties (Milfa Nurdiana, 2019). Therefore, every teacher needs the right strategy in learning so that the results do not disappoint. (Ilahiyah, Yandari, \& Pamungkas, 2019).

The unsatisfactory results obtained by students can be triggered by several problems, such as the number of students who often underestimate or consider it difficult and difficult to learn mathematics, the learning process that takes place is less interesting so students will quickly feel bored, and the lack of student activity in learning mathematics. They even ask questions and even get the material and answer the questions given and are reluctant to ask even though there is a lot of material that they may not understand, and many students do not pay attention to the teacher's explanation. However, learning difficulties can be classified into 2, namely development learning disabilities and academic learning (Abdurrahman, 2012). (Abdurrahman, 2012).

Or maybe it could happen because students' understanding of online learning is still low and not maximized (AYU, 2021) Because basically, students who have learned to use e-Learning will be more effective than others (Muharto, Hasan, \& Ambarita, 2017). The purpose of this study was to determine (1) mathematics learning outcomes, (2) the influence of WhatsApp media on students' mathematics learning outcomes. As previously explained, this thesis takes the title "The Effect of Online Learning Through WhatsApp Group Media on the Learning Outcomes of Class VII Students of BuluChinese Private Junior High School".

\section{METHOD}

This research was conducted at the BuluCina Private School, which is located at Jalan Limo MirihBuluCina, Kec. Hamparian Perak Kab. Deli Serdang, North Sumatra Province.

This study uses a design in the form of quantitative research, which is a systematic scientific study of the parts and phenomena and the quality of their relationships. The purpose of quantitative research is to develop and use mathematical models, theories, and/or hypotheses related to natural phenomena. The measurement process is a central part of quantitative research because it provides a fundamental link between empirical observations and the mathematical expression of quantitative relationships.

The data sources of this research are tests and questionnaires in the form of a questionnaire about the learning difficulties of the students of BuluCinaSwadaya Junior High School. The number of tests given is 3 tests. And the number of questionnaire statements totaled 28. The instrument used in this study was questionnaire data collection, the data were analyzed using statistical description analysis through the following steps: (1) data 
reduction, (2) data presentation, and (4) conclusions.

Data reduction is selecting data that is needed and less important. Furthermore, relevant data is classified based on its type and less relevant data is removed. After the data is reduced and classified, the data collected through documentation is presented by the number of questionnaire scores. Presentation of data is a collection of conclusions and taking action. By presenting the data, it will be easier to understand what happened and plan the next action.

The method used to collect the data needed in research to answer the formulation of the research problem is called data collection techniques. In this study the data collection techniques used include:

1. Questionnaire Questioner

The questionnaire is a data collection technique that is carried out by giving a set of questions or statements that will be given to respondents to be answered. The results of the questionnaire in this study serve to provide information to readers related to the answers from respondents, and the use of this questionnaire to obtain data about the use of learning media.

The data collected in this study is related to the effect of using media in learning. The type of questionnaire used in this study is a direct questionnaire, which is in the form of a Likert scale with closed questions, namely the answers to the questions asked are available.

2. Test

The test is a measuring instrument for data collection that is used to measure something with certain rules. The test is used to determine student learning outcomes before and after the implementation of learning through WhatsApp media. The test was given twice, namely the ability test for learning outcomes in pre-test I and testability for learning outcomes II in post-test II, each test numbered 3. In this study, the test used was a written test. The test used in this study is an essay test.

\section{RESULTS AND DISCUSSION}

In this study, conclusions are drawn based on the indicators of success that have been achieved until action II, namely: a. A total of 36 students are said to have completed their studies because these students have reached the KKM score of 75 from the material being taught. b. Class VII of BuluCina Private Junior High School is said to have finished studying classically because the class reached $85 \%$ of the total number of students who got an average grade with a KKM of 75. Learning is said to have been effective because of the results of learning observations included in the very good or good category.

Student response data regarding the use of WhatsApp Group media on learning outcomes is known from the distribution of questionnaires and tests. The student response questionnaire to learning difficulties consists of 28 statements developed from the indicators as listed in the instrument grid. Student response questionnaires were given to the experimental class after expert validation. Data collection was taken from the experimental class, which consisted of 36 students. The student response questionnaire data obtained is variable $X$ data. The purpose of the description of the data regarding responses regarding the use of WhatsApp group media on learning outcomes is to find out how the influence of online learning in mathematics on the subject of the set. The author calculates student response questionnaires in several ways.

First, the authors calculated the results of the student response questionnaire scores on learning difficulties in mathematics obtained by all seventh-grade students using Ms. Excel. The results of the questionnaire scores on student responses to the learning difficulties questionnaire from numbers 1 to 28 can be seen in the table. Second, the student response questionnaire score data on learning difficulties obtained were then processed and analyzed using SPSS 16.00 assistance. 
Table. 1

DeskriptifStatistik

\begin{tabular}{lccccccccc}
\hline \multicolumn{10}{c}{ DESCRIPTIVE STATISTICS } \\
\hline & $\mathbf{N}$ & $\begin{array}{c}\text { Rang } \\
\text { e }\end{array}$ & $\begin{array}{c}\text { Mi } \\
\mathbf{N}\end{array}$ & Max & Sum & $\begin{array}{c}\text { Mea } \\
\mathbf{n}\end{array}$ & $\begin{array}{c}\text { Std } \\
\text { Deviatio } \\
\mathbf{n}\end{array}$ & Variance \\
\hline Questionnaire_diff & 36 & 44 & 64 & 108 & 3128 & 898 & 9585 & 91.873
\end{tabular}

iculty_learning

Valid N (listwise) 36

Third, the authors process the data using the percentage form. The author's goal is to present the results of the questionnaire in the form of percentages to determine the percentage of each

item and the cumulative percentage of each indicator. The data description is the percentage of

each statement item and the cumulative percentage for each indicator of the student response questionnaire.

Table.2

Cumulative Percentage of Student Responses Indicator I

\begin{tabular}{lll}
\hline $\begin{array}{l}\text { Item } \\
\text { Number }\end{array}$ & F & $\begin{array}{l}\text { Sum } \\
\text { Score }\end{array}$ \\
\hline $1,2,3,4,6$, & 90 & 360 \\
20, & & \\
\hline 27 & 90 & 370 \\
\hline & 65 & 130 \\
\hline & 16 & 16 \\
\hline Sum & 261 & 776 \\
\hline
\end{tabular}

A normality test is conducted to determine whether or not a data distribution is normal. Good data is having a normal data

distribution or is close to normal. To test for normality, it can be analyzed using the OneSample Kolmogorov Smirnov Test method. The basis for the decision is if the statistical probability value $>$ Level of Significant $=$ 0.05 , then the regression model meets the assumption of normality. The decision-making criteria in the normality test are as follows: 1 ) If the significance value/P-value/Sig $<0.05$ means the data is not normal, 2) If the significance value/P-value/Sig > 0.05 means the data is normal. SPSS 16.00 assistance in testing the normality of the data.

Table 3

Normality Test

Descriptive Statistics

\begin{tabular}{rllll}
\hline $\mathrm{N}$ & Mean & Std. Dev & Min & Max \\
\hline 36 & 67.53 & 13.190 & 50 & 100 \\
\hline post_test 36 & 83.50 & 5.959 & 75 & 100 \\
\hline
\end{tabular}

The significant test used in this study is the t-test, which then determines the significance level to determine the hypothesis proposed in the study.

Table 4

Uji-TOne-Sample Test

\begin{tabular}{|c|c|c|c|c|c|c|}
\hline & \multicolumn{6}{|c|}{ Test Value $=0$} \\
\hline & $\mathrm{T}$ & df & $\begin{array}{l}\text { Sig. (2- } \\
\text { tailed) }\end{array}$ & Mean Difference & $\begin{array}{l}95 \% \\
\text { Inter } \\
\text { Dif }\end{array}$ & $\begin{array}{l}\text { nfidence } \\
\text { ll of the } \\
\text { rence }\end{array}$ \\
\hline & & & & Low & & per \\
\hline Learning result pretest & 30.718 & 35 & .006 & 67.528 & 63.06 & 71.99 \\
\hline Learning result posttes & 84.069 & 35 & .006 & 83.500 & 81.48 & 85.52 \\
\hline
\end{tabular}

Based on table 4.4 that the value of Sig. (2-tailed) which is 0.006 , and looking at the test criteria $<0.05$, it is found that the results of the t-test reject $\mathrm{HO}$ and accept $\mathrm{Ha}$, meaning that there is an effect of online learning through WhatsApp Group media on the learning outcomes of Class VII students of BuluCinaSwadaya Junior High School. This 
study showed that the experimental class got an average pretest score of 67.53 , while the post-test was 83.50 . and the lowest score in the pre-test class was 50 , while the post-test was 75.

It means that it can be concluded that learning using WhatsApp media has fairly good effectiveness than learning without using media.

This can be shown from the results of the calculation of the average post-test value in the

experimental class which is higher at 83.50. The results of the paired t-test, obtained are sig. 2 tailed of $0.006<0.05$ which means that there is a the significant effect between the average value before treatment (pre-test) and the average value after treatment (post-test).

WhatsApp teaching media will open up opportunities for students to learn according to their own pace and way. Therefore, they use different techniques in solving problems with their respective background knowledge and habits. With WhatsApp media, students are expected to be able to practice independently, dare to express opinions, and learn to develop logical thinking and reasoning.

A teaching process can be said to be successful if the lesson can generate an effective learning process. In addition, WhatsApp media makes students clearer in understanding the material because the material presented in it is short and clear.

\section{CONCLUSION}

Based on the results of research and discussion, it can be concluded that learning using media in mathematics is more effective and can improve learning outcomes. Thus, the proposed action hypothesis can be accepted. These results in detail can be stated as follows: 1). In the experimental class, namely class VII SMP, the average pretest score was 67.53 , while the post-test was 83.50 higher than before using WhatsApp media. 2). There is an Influence of Online Learning Through WhatsApp Group Media on the Learning Outcomes of Class VII Students of BuluCina Private Junior High School.

\section{REFERENCES}

Abdurrahman, Mulyono. (2012). Anak Berkesulitan Belajar.Google Scholar

Adhe, Pertiwi Kurniasih. (2021). Pengaruh Pendampingan Orangtua Dalam Pembelajaran Online Terhadap Hasil Belajar Matematika Kelas V Sd/Mi Bandar Lampung. Uin Raden Intan Lampung. Google Scholar

Albano, Giovannina. (2012). A KnowledgeSkill-Competencies E-Learning Model In Mathematics. Rusc, Universities And Knowledge Society Journal, 9(1), 306319. Google Scholar

Amaniyah, Inqidloatul, Rahmawati, Ika, \& Lailiyah, Siti. (2021). As Efektivitas Pembelajaran Daring Menggunakan Google Meet Dan Whatsapp Group Untuk Meningkatkan Hasil Belajar Matematika Selama Pandemi Covid 19. Modeling: Jurnal Program Studi Pgmi, 8(1), 28-42. Google Scholar

Auliya, Risma Nurul. (2016). Kecemasan Matematika Dan Pemahaman Matematis. Formatif: Jurnal IImiah Pendidikan Mipa, 6(1). Google Scholar

Ayu, Desiyanti. (2021). Kajian Implementasi E-Learning Berbasis Aplikasi Whatsapp Terhadap Keefektivan Dan Efisiensi Belajar Peserta Didik Dampak Wabah Covid-19 Ranah Sd/Mi. Uin Raden Intan Lampung. Google Scholar

Fuady, Muhammad Jauharul. (2017). Pengembangan Aplikasi Evaluasi Pembelajaran Online Untuk Pendidikan Jarak Jauh. Tekno, 26(2). Google Scholar

Ilahiyah, Nihlatul, Yandari, Indhira Asih Vivi, \& Pamungkas, Aan Subhan. (2019). Pengembangan Modul Matematika Berbasis Pakem Pada Materi Bilangan Pecahan Di Sd. Terampil: Jurnal Pendidikan Dan Pembelajaran Dasar, 6(1), 49-63. Google Scholar

Milfa Nurdiana, Maulin. (2019). Upaya Guru Dalam Meningkatkan Kesadaran 
Beragama Anak Usia Dini Di Tk Pertiwi Karangpule Kecamatan Padamara Kabupaten Purbalingga. Iain Purwokerto. Google Scholar

Muharto, Muharto, Hasan, Syahril, \& Ambarita, Arisandy. (2017). Penggunaan Model E-Learning Dalam Meningkatkan Hasil Belajar Mahasiswa Pada Materi Microprocessor. Indonesian Journal On Information Systems, 2(1), 260157. Google Scholar

Nurdiantoro, Faisal. (2018). Kesulitan Belajar Matematika Peserta Didik Kelas Iv Sd Negeri 3 Rejoagung Kedungwaru Tulungagung. Google Scholar

Rusman, M. Pd, \& Cepi, Riyana. (2012). Belajar Dan Pembelajaran Berbasis Komputer. Bandung: Alfabeta. Google
Scholar

Solikhah, Imro Atus. (2019). Peningkatan Hasil Belajar Matematika Menggunakan Metode Discovery Learning Pada Peserta Didik Kelas Iv A Di Sdit Miftahul Jannah Rajabasa Bandar Lampung. Uin Raden Intan Lampung. Google Scholar

Widada, Wahyu. (2015). The Existence Of Students In Trans Extended Cognitive Development On Learning Of Graph Theory. Jurnal Math Educator Nusantara, 1(1), 1-20. Google Scholar

Yuliana, Yuliana. (2020). Corona Virus Diseases (Covid-19): Sebuah Tinjauan Literatur. Wellness And Healthy Magazine, 2(1), 187-192. Google Scholar

\section{Copyright holder:}

Irwan, Mardiati, Lilis Saputri, Seget Tartiyoso, Efrini Panjaitan (2021)

First publication right:

Journal of Social Science

This article is licensed under:

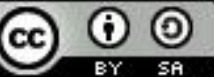

